Available online: https://journal.uny.ac.id/index.php/jpa

Jurnal Pendidikan Anak, Volume 9 (1), 2020, 57-62

\title{
Peran orang tua dalam menghilangkan rasa canggung anak usia dini (studi kasus di desa karangbong rt. 06 rw. 02 Gedangan-Sidoarjo)
}

\author{
Syifaul Adhimah \\ Program Studi Pendidikan Guru Pendidikan Anak Usia Dini \\ Fakultas Pendidikan Dasar, Universitas Negeri Surabaya \\ Jl. Rektorat Unesa, Lidah Wetan, Kec. Lakarsantri, Kota SBY, Jawa Timur 60213, Indonesia \\ E-mail: syifaul.adhimah@gmail.com
}

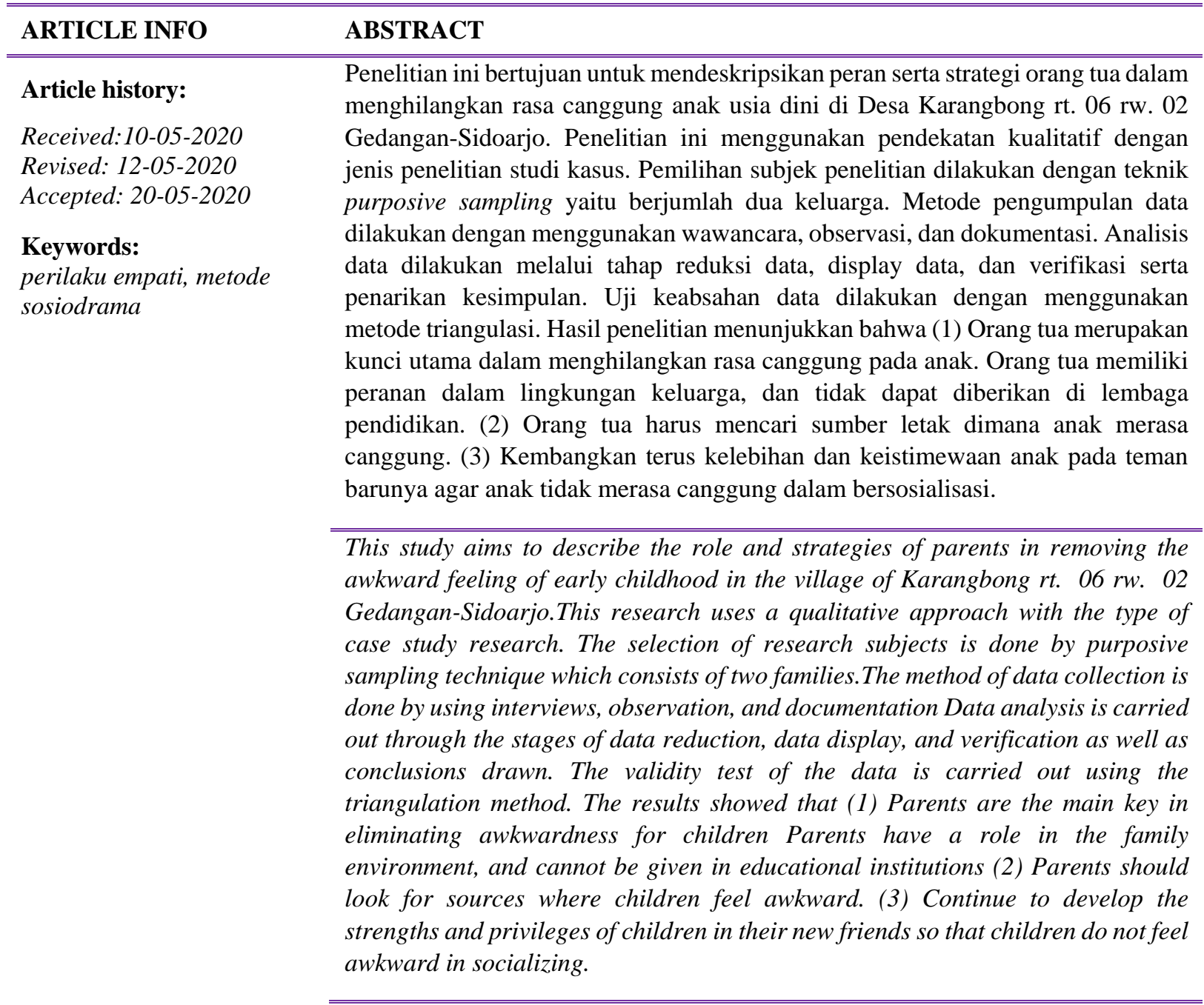

\section{PENDAHULUAN}

Dunia pendidikan merupakan lingkup penting dalam menentukan masa depan dan kemajuan suatu bangsa. Pendidikan dapat menggerakkan generasi bangsa untuk terus menggali ilmu sebagai bekal membangun kehidupan yang lebih baik. Tujuan pendidikan yang beorientasi pada masa depan tercermin dalam UU Nomor 20 Tahun 2003 tentang Sistem Pendidikan Nasional yaitu untuk mengembangkan potensi peserta didik agar menjadi manusia yang beriman dan bertakwa kepada Tuhan Yang Maha Esa, berakhlak mulia, sehat, berilmu, cakap, kreatif, mandiri, dan menjadi warga negara yang demokratis serta bertanggung jawab.

Bentuk dukungan pemerintah untuk mencapai tujuan pendidikan nasional diwujudkan dengan adanya layanan pendidikan sejak usia dini. Sebagaimana disebutkan dalam UU Sisdiknas No.20 Tahun 2003 bahwa PAUD merupakan suatu upaya pembinaan yang ditujukan kepada anak sejak lahir sampai 
Jurnal Pendidikan Anak, Volume 9 (1), Tahun 2020

Syifaul Adhimah

dengan usia enam tahun yang dilakukan melalui pemberian rangsangan pendidikan untuk membantu pertumbuhan dan perkembangan jasmani dan rohani agar anak memiliki kesiapan dalam memasuki pendidikan lebih lanjut (Fadlillah dan Khorida, 2013).

Dalam Pendidikan Anak Usia Dini terdapat enam aspek perkembangan yaitu nilai agama dan moral, kognitif, fisik motorik, bahasa, sosial emosional dan seni. Salah satu aspek perkembangan yang menjadi fokus dalam penelitian ini adalah sosial emosional anak.

Anak usia dini pada umumnya berada pada tahapan suka bermain, suka bereksplorasi, dan mempunyai banyak teman. Seiring bertambahnya usia anak, maka anak akan bertemu dengan orangorang baru dan mulai menjalin sosialisasi. Sesuai dengan tahapan perkembangan anak usia dini pada aspek sosialnya diharapkan anak dapat akrab dengan teman dan orang-orang yang ada disekitarnya, anak juga diharapkan untuk bias mengungkapkan ide, gagasan, dan pikirannya saat sedang bersosialisasi dengan teman sebayanya. Namun berdasarkan hasil observasi di lapangan, masih banyak anak usia dini yang masih didominasi oleh sikp-sikap tidak percaya diri, seperti canggung dalam bertemu orang baru.

Perilaku yang ditemui saat observasi anak-anak ketika berada di lingkungan rumah adalah masih terdapat 2 anak yang mempunyai rasa canggung. Ia tidak suka bermain dengan teman orang baru. Mereka cenderung sangat pemalu bahkan tidak mau berbicara dengan orang yang jarang ditemuinya. Hal ini mengakibatkan sosial emosional anak tehambat karena mereka tidak mempunyai kepercayaan pada dirinya sendiri.

Definisi canggung adalah kurang mahir atau kurang terampil dalam menggunakan sesuatu (karena belum biasa mengerjakannya). Canggung merupakan sesuatu fenomena yang biasa dalam kehidupan. Canggung secara teori merupakan suatu keadaan dimana seorang anak tidak biasa dalam melakukan kegiatan tertentu. Akibatnya si anak akan merasa kebingungan. Rasa canggung adalah reaksi takut terhadap manusia, bukan pada obyek atau situasi. Rasa canggung biasanya disebabkan oleh keraguan-raguan tentang penilaian orang lain terhadap prilaku atau dirinya. Oleh karena itu, rasa canggung merupakan keadaan khawatir yang menyangkut kesadaran-diri (selfconscious distress).

Pada masa pandemi seperti ini, peran orang tua sangat penting dalam menghilangkan rasa canggung anak dalam bertemu orang-orang baru disekitarnya, terutama teman sebaya didesanya. Agar tumbuh kembang anak tidak terhambat dan upaya pendidikan dalam keluarga tercapai. Kesadaran orang tua tentang pentingnya pendidikan anak usia dini sangatlah penting karena mereka mempunyai peranan yang penting dalam mendidik anak. Antara orang tua dengan pendidikan adalah dua istilah yang tidak bisa dipisahkan. Sebab, dimana ada orang tua disitu ada pendidikan. Dimana ada orang tua disitu ada anak merupakan suatu kemestian dalam keluarga. Ketika ada orang tua yang ingin mendidik anaknya, maka pada waktu yang sama, ada anak yang menghajatkan pendidikan dari orang tua. Dari sinilah munculah istilah "pendidikan keluarga". Artinya, pendidikan yang berlangsung dalam keluarga dilaksanakan oleh orang tua sebagai tugas dan tanggung jawabnya dalam mendidik anak dalam keluarga.

Berdasarkan hubungan sosial, keluarga adalah suatu kesatuan yang diikat oleh adanya hubungan atau interaksi dan saling mempengaruhi antara satu dengan yang lainnya, walaupun diantara mereka tidak terdapat hubungan darah. Dalam perspektif yang lain, keluarga disebut juga sebagai sebuah persekutuan antara ayah, ibu dengan anak- anaknya yang hidup bersama dalam situasi yang terbentuk karena ikatan perkawinan yang sah menurut hukum, dimana di dalamnya ada interaksi (saling berhubungan dan mempengaruhi) antara satu dengan yang lainnya. Dari uraian dapat disimpulkan bahwa orang merupakan sebuah intitusi pendidikan yang utama dan bersifat kodrati. Sebagai komunitas masyarakat terkecil, orang tua memeliki arti penting dan strategis dalam membangun komunitas masyarakat yang lebih luas. Oleh karena itu, kehidupan keluarga yang harmonis perlu dibangun.

Orang tua mempunyai peran yang sangat penting dalam perkembangan anak usia dini. Ketika anak mengalami hambatan dalam perkembangannya, maka orang tua harus mensupport anak agar perkembangannya tidak mengalami kendala. Anak yang mempunyai rasa canggung, biasanya karena anak mengalami ketakutan terhadap orang-orang baru dan anak kurang bersosialisasi dengan lingkungan sekitarnya. Maka dari itu, peran orang tua sangat penting dalam menghilangkan rasa canggung pada anak. Karena dengan adanya dorongan, motivasi, dan keterlibatan orang tua dalam tumbuh kembang anak, akan menjadikan anak berani untuk tampil dan berkenalan dengan orang baru disekitarnya.

Berdasarkan kenyataan dan permasalahan terkait rasa canggung anak, maka penulis tertarik untuk meneliti secara mendalam terkait peran orang tua dalam menghilangkan rasa canggung anak usia 
Jurnal Pendidikan Anak, Volume 9 (1), Tahun 2020

Syifaul Adhimah

dini di desa Karangbong rt. 06 rw. 02 Gedangan-Sidoarjo. Tujuan yang diharapkan dalam penelitian ini adalah Untuk mengetahui peran serta strategi orang tua dalam menghilangkan rasa canggung anak usia dini di Desa Karangbong rt. 06 rw. 02 Gedangan-Sidoarjo.

\section{METODE}

Pendekatan yang digunakan dalam penelitian ini adalah pendekatan kualitatif yang digunakan untuk mengetahui atau menggambarkan kenyataan dari kejadian yang diteliti sehingga memudahkan mendapatkan data yang objektif. Sugiyono (2015: p 209) menyebutkan bahwa metode penelitian kualitatif digunakan peneliti pada kondisi objek yang alamiah. Menurut Moleong (2009: p 6), penelitian kualitatif adalah "penelitian yang bermaksud untuk memahami fenomena tentang apa yang dialami oleh subjek penelitian misalnya perilaku, persepsi, motivasi, tindakan, dll., secara holistik, dan dengan cara deskripsi dalam bentuk kata-kata dan bahasa, pada suatu konteks khusus yang alamiah dan dengan memanfaatkan berbagai metode alamiah".

Berdasarkan pengertian di atas dapat diketahui bahwa penelitian kualitatif merupakan penelitian yang bersifat alamiah dan data yang dihasilkan berupa deskriptif. Pada penelitian ini menggunakan pendekatan kualitatif dengan jenis penelitian studi kasus. Penelitian ini memusatkan diri secara intensif pada satu obyek tertentu yang mempelajarinya sebagai suatu kasus. Data studi kasus dapat diperoleh dari semua pihak yang bersangkutan.

Subjek penelitian merupakan sumber data yang dapat memberikan informasi terkait dengan permasalahan penelitian yang diteliti. Teknik pengambilan subjek penelitian menggunakan teknik purposive sampling yakni dipilih dengan pertimbangan dan tujuan tertentu (Sugiyono, 2015: p 216).

Adapun keriteria yang ditentukan oleh peneliti sebagai subjek penelitian adalah mereka yang terlibat pada kegiatan yang diteliti, mengetahui dan memahami informasi terkait penelitian. Berdasarkan hal tersebut, subjek dalam penelitian ini dipilih dengan kriteria sebagai berikut:

1. Keluarga bertempat tinggal di Desa Karangbong rt. 06 rw. 02 Gedangan-Sidoarjo.

2. Keluarga yang memiliki anak usia dini dengan rasa canggung.

3. Bersedia untuk di wawancara

Pada penelitian ini yaitu dua keluarga yang berada di Desa Karangbong rt. 06 rw. 02 GedanganSidoarjo. Ke dua keluarga dipilih yaitu dan memiliki latar belakang profesi yang berbeda-beda didasarkan kepada pertimbangan bahwa penelitian kualitatif lebih mementingkan informasi yang banyak daripada banyaknya jumlah informan. Oleh karena itu, maka penetapan subjek penelitian ini dilakukan dengan menggunakan teknik purposive atau sesuai dengan tujuan atau kriteria populasi penelitian. Adapun data informan terdapat pada Tabel 1 berikut ini.

Tabel 1. Data informan

\begin{tabular}{lll}
\hline No. & Nama & \multicolumn{1}{c}{ Keterangan } \\
1. & UM & $\begin{array}{l}\text { Ibu setengah berusia } 36 \text { tahun, pekerjaan buruh pabrik, pendidikan terakhir } \\
\text { SMA. }\end{array}$ \\
Bapak setengah baya berusia 31 tahun, pekerjaan satpam. Memiliki seorang \\
anak berusia 9 tahun dan 4 tahun. \\
Ibu muda berusia 29 tahun, pekerjaan buruh pabrik, pendidikan terakhir \\
2. & MKR & $\begin{array}{l}\text { SMA. } \\
\text { Bapak setengah baya berusia } 32 \text { tahun, pekerjaan jualan kopi. Memiliki } \\
\text { seorang anak berusia } 8 \text { tahun dan } 5 \text { tahun }\end{array}$ \\
\hline
\end{tabular}

Teknik pengumpulan data yang digunakan dalam penelitian ini adalah:

1. Wawancara

Menurut Arikunto (2010: 270) wawancara mula-mula menanyakan serentetan pertanyaan yang sudah terstruktur, kemudian satu persatu diperdalam dengan mencari keterangan lebih lanjut. Dengan pedoman pertanyaan yang sudah dibuat diharapkan pertanyaan dan pernyataan responden lebih terarah dan memudahkan untuk rekapitulasi catatan hasil pengumpulan data penelitian. Pada wawancara, peneliti meminta supaya responden memberikan informan sesuai dengan yang dialami, 
Jurnal Pendidikan Anak, Volume 9 (1), Tahun 2020

Syifaul Adhimah

diperbuat, atau dirasakan sehari-hari dalam hal menanamkan kedisiplinan kepada anak usia dini dalam lingkungan keluarga masing- masing.

Tujuan dilakukan wawancara adalah untuk menggali informasi secara langsung dan mendalam dari beberapa informan yang terlibat. Wawancara dilakukan dengan tatap muka langsung dengan informan, sehingga terjadi kontak pribadi dan melihat langsung kondisi informan.

2. Observasi

Menurut Sugiyono (2015: p 227), penelitian dimulai dengan mencatat, menganalisis dan selanjutnya membuat kesimpulan tentang pelaksanaan dan hasil program yang dilihat dari ada atau tidaknya perkembangan usaha yang dimiliki warga belajar. Penelitian ini menggunakan teknik observasi nonpartisipan, karena peneliti tidak terlibat dan hanya sebagai pengamat independen.

3. Dokumentasi

Teknik pengumpulan data berikutnya yang digunakan oleh penulis, yaitu dokumentasi. dokumentasi ini digunakan penulis untuk mengumpulkan data peristiwa yang sudah berlalu. Dokumentasi ini berbentuk rekaman dan foto. Teknik analisis data yang digunakan dalam penelitian ini adalah menggunakan langkah-langkah seperti yang dikemukakan oleh Burhan Bungin (2003: p 70), yaitu sebagai berikut: pengumpulan data (data collection), reduksi data (data reduction), dan verifikasi dan penegasan kesimpulan.

Penelitian ini menggunakan metode triangulasi data sebagai teknik pengukuran keabsahan data. Menurut Wirawan (2011: p 156), triangulasi adalah suatu pendekatan riset yang memakai suatu kombinasi lebih dari satu strategi dalam satu penelitian untuk menjaring data/informasi. Dengan mengumpulkan dan membandingkan multipel data set satu sama lain, triangulasi membantu meniadakan ancaman bagi setiap validitas dan reliabilitas data.

Penelitian ini menggunakan triangulasi metode seperti yang dijelaskan oleh Moleong (2004: 330). Triangulasi metode dilakukan dengan cara membandingkan informasi atau data dengan cara yang berbeda. Peneliti menggunakan teknik yang berbeda-beda untuk mendapatkan data dari sumber yang sama. Peneliti dapat menggunakan observasi, wawancara mendalam, dan dokumentasi. Melalui berbagai perspektif diharapkan diperoleh hasil yang mendekati kebenaran. Karena itu, triangulasi tahap ini dilakukan jika data atau informasi yang diperoleh dari subjek atau informan penelitian diragukan kebenarannya.

Penelitian ini dilakukan dengan membandingkan data peran orang tua dalam menghilangkan rasa canggung anak usia dini yang diperoleh melalui teknik wawancara, dokumentasi dan observasi. Peneliti melakukan wawancara terhadap orang tua tentang peran masing-masing komponen tersebut. Kemudian untuk mengecek kebenaran hasil wawancara, peneliti menggunakan obervasi atau pengamatan dengan melihat langsung kondisi keluarga.

\section{HASIL DAN PEMBAHASAN}

\section{Hasil}

Penelitian ini dilakukan di Desa Karangbong rt. 06 rw. 02 Gedangan-Sidoarjo, Jawa Timur.

Dalam penelitian ini yang dijadikan subjek adalah dua keluarga yang mempunyai profesi yang berbeda antara lain: buruh pabrik, satpam, dan penjual kopi. Jumlah sumber data penelitian didasarkan pada pertimbangan bahwa penelitian kualitatif lebih mementingkan informasi yang banyak daripada banyaknya jumlah informan.

Hasil dari wawancara dua orang tua yang memiliki anak dengan rasa canggung di lapangan ialah dampak anak memiliki rasa canggung adalah dia akan sulit berinteraksi dan bergaul dengan lingkungan disekitarnya. Orang tua merupakan kunci yang paling penting didalam menghilangkan rasa canggung pada anak sejak dini, dan peran orang tua inilah yang tidak dapat diberikan di lembaga pendidikan. Anak yang mempunyai rasa canggung akan merasa dikucilkan oleh lingkungannya. Anak akan ragu dalam melakukan sesuatu hal karena dia takut orang akan menilai buruk tentang perilaku yang dilakukannya. Biasanya anak yang mempunyai rasa canggung lebih memilih menghindar dari sesuatu yang memperhatikan dirinya. Sifat canggung yang dimiliki anak akan membuat anak kehilangan banyak kesempatan dan membawa banyak kerugian. 


\section{Pembahasan}

Rasa canggung adalah sebuah kombinasi dari kegugupan sosial dan pengkondisian sosial. Formula dari rasa canggung terdiri dari "terlalu berpusat pada diri sendiri” dicampur dengan rasa gugup. Dibutuhkan usaha untuk mengarahkan diri anak untuk tidak terlalu berpusat pada diri sendiri dan penilaian orang lain terhadap dirinya. Reaksi anak terhadap seseorang ataupun sebuah peristiwa, sangat dipengaruhi oleh cara berpikirnya. Anak dengan kepercayaan diri yang lemah, cenderung mempersepsi segala sesuatu dari sisi negatif. Strategi yang tepat untuk menghilangkan rasa canggung pada anak usia dini adalah:

1. Hindarkan anak untuk terlalu memperhatikan dirinya. Maksudnya fokuskan anak pada apa yang akan dia lakukan. Berilah semangat untuk menumbuhkan rasa percaya dirinya. Ajak anak untuk bersantai agar perasaan canggung dan gugupnya hilang, sehingga anak akan merasa lebih tenang.

2. Ajak anak bersosialisasi dengan teman sebayanya yang baru. Selain itu ajak si anak dan temannya untuk berkenalan dan bercerita satu sama lain. Jika anak tidak mau melakukannya dan hanya diam, berilah anak gurauan yang membuatnya tidak tegang saat berkenalan, sehingga anak tidak akan mengalami kecanggungan.

3. Mencari sumber letak dimana anak merasa canggung. Hal ini akan membantu anak menghilangkan rasa canggung dan gugup yang ada pada dirinya.

4. Kembangkan terus kelebihan dan keistimewaan anak pada teman barunya, agar anak tidak merasa canggung dan anak akan mempunyai kepercayaan diri yang tinggi.

5. Ajak anak untuk bersosialisasi terus-menerus dengan teman-temannya, dan dorong anak-anak untuk akrab satu sama lain.

6. Membiasakan anak melakukan kegiatan yang membuatnya canggung, karena biasanya anak mempunyai rasa canggung karena belum pernah atau hanya sekali saja melakukan kegiatan tersebut.

\section{SIMPULAN}

Berdasarkan pembahasan yang telah disampaikan, dapat diambil kesimpulan bahwa Setiap anak memiliki karakter dan sifat yang berbeda-beda. tumbuh kembang anak tergantung pada interaksinya dalam suatu lingkungan. Anak akan mudah berinteraksi jika berada dilingkungan yang menurutnya nyaman. Mengembangkan sosial dan emosional anak yang mempunyai rasa canggung bukan hal yang menyulitkan. Itu semua tergantung bagaimana strategi guru atau orang tua untuk menghilangkan rasa canggung pada anak. Karena pada masa inilah yang akan membentuk anak ketika dewasa. Rasa canggung pada anak sering sekali kita jumpai. Disinilah peran orang tua sangat penting untuk menghilangkan rasa canggung yang ada dalam diri anak. Dalam penelitian yang saya lakukan, saya akan memeberikan saya memberikan beberapa saran yang dapat dilakukan sebagai berikut:

1. Berikan stimulus dan respon yang baik terhadap anak. Jika anak canggung untuk melakukan sesuatu, berikan rangsangan seperti memberi perhatian lebih agar anak tersebut tidak canggung lagi.

2. Berikan kemudahan kepada anak untuk bersosialisasi dengan teman atau orang yang disekitarnya.

3. Kembangkan perkembangan sosial dan emosional anak secara terus-menerus dengan tahapan yang benar dan efektif untuk anak.

\section{UCAPAN TERIMA KASIH}

Ucapan terimakasih diucapkan kepada kedua keluarga Desa Karangbong rt. 06 rw.02 Gedangan-Sidoarjo atas kesempatan yang telah diberikan kepada peneliti untuk melakukan penelitian. 
Jurnal Pendidikan Anak, Volume 9 (1), Tahun 2020

Syifaul Adhimah

\section{DAFTAR PUSTAKA}

Arikunto, S. (2010). Prosedur penelitian suatu pendekatan praktik. Jakarta: PT. Rineka Cipta.

Bridgemohan, R.R. (2001). Parent involvement in early childhood development in kwazulu natal. Thesis.

Bungin, B. (2001). Metodologi penelitian kualitatif. Surabaya: PT. Pustaka Pelajar.

Ceka, A. \& Murati, R. (2016). The role of parents in the education of children. Journal of Education and Practice, 7, 62-63.

Landry, S.H. (2008). The Role of parents in early childhood learning. Encylopedia on Early Childhood Development (online).

Moleong, L.J. (2005). Metodologi penelitian kualitatif. Bandung: Remaja Rosdakarya.

Permono, H. (2013). Peran orang tua dalam optimalisasi tumbuh kembang anak untuk membangun karakter anak usia dini. Jurnal Universitas Muhammadiyah Surakarta (Online).

Pratisi, W.D. (2013). Peran orang tua dalam perkembangan kemampuan regulasi emosi anak: model teoritis. Jurnal Universitas Muhammadiyah Surakarta (Online).

Sugiyono. (2015). Metode penelitian pendidikan (pendekatan kuantitatif, kualitatif, dan $r \& d$ ). Bandung: Penerbit Alfabeta. 